Kamila Gandecka

\title{
“FAMILY. OH! THE FAMILY!" - PORTRAYALS OF FAMILY AS AN EDUCATIONAL ENVIRONMENT IN SELECTED LITERARY WORKS FROM THE 19TH AND 20TH CENTURIES
}

\begin{abstract}
Annotation. The family, as the basic microstructure of social life, constitutes, at the very least by supposition, the first and foremost educational environment of a child; an environment which should correspond to the child's natural needs, especially psychological ones, such as the need for love, unconditional acceptance, the need for respect and recognition, activity, independence, and self-realization [9]. This why M. Lukšienè states, "A good family home is the basis of human physical and spiritual life; it guarantees one's efficient, creative activity" [1].
\end{abstract}

The parents' worldview plays an important role in education, providing an answer to the fundamental questions concerning our existence: Who am I? What sense does my life have? What is the goal of my life? What ideals and rules of action do I represent? What is the world and my place within it? Undoubtedly, a variety of factors affect the shaping of a young person's worldview, among them school, religion, ideology, the level of social development, social organization, the particular historical period in which the person lives, as well as certain individual psychological predispositions. Nevertheless, parents have always played the pivotal role in the shaping of children's worldview. Parents prepare their children for an independent life in society by teaching them values, norms, models of behavior, and cultural customs. In this way, parents fulfill their function as a microstructure, fulfilling aims that support the macrostructure.

Beginning with the second half of the 19th century, the notion of the family becomes one of the main themes in Polish literature, appearing in the works of such authors as Bolesław Prus, Henryk Sienkiewicz, Eliza Orzeszkowa, Stefan Żeromski, Władysław Reymont, and Maria Konopnicka. Moreover, the literary representation of the family as an educational environment of a child is also often evoked in the theoretical musings of professionals in the field of education. These professionals include Helena Radlińska, Jerzy Ostrowski, Janusz Korczak, and Aleksandra Kamiński.

In conclusion, the broadly defined notion of family is, without question, universal and timeless.
As an area of scholarly inquiry, it requires an interdisciplinary approach that encompasses all possible perspectives.

Keywords: family, educational environment, education, teaching values, theme of family home and family in 19th and 20th century literature.

\section{Introduction}

An analysis of historical family structures and their transformations, motivations, and developmental trends allows historians to understand the transformations of an entire past society. A thorough investigation of such structures should also uncover the symptoms of mechanisms of societal development. Moreover, according to K. Jakubiak and A. Winiarz: "Historical and pedagogical research on family as an educational environment, apart from pursuing pure knowledge, should have a practical aspect as well. Its results should inform our musings on education in the contemporary family" [3].

Precisely because the family has always constituted the elementary cell on which the society is based, the themes of family home and family (very closely related and co-existing) are present in the works of authors of all historical periods. The beauty of the family home and the family is reflected, for instance, in the poem by Tadeusz Boy-Żeleński entitled "A Song of a Painter's Home": "There is nothing better than family life / Honest and happy, inexpensive and healthy; / Is there anyone who does not yearn / For one's bucolic parental home, / <... Everyone adorns one's home in beautiful glory / And surrounds it with love, Platonic though it may be" [2]. It is family homes that, similar to churches and cemeteries, have become places of special importance. They protect tradition, memory, and faith - powers capable of sparking and maintaining national feelings. The tragedies that were the partitions of Poland did not destroy the Polish home; on the contrary, they caused the family home to be permanently consolidated as a value [5].

The development of pedagogical investigation into the family as a basic educational environment intensified in Poland during the Partitions. At that 
time, the role of family increased due to the young generations being taught values that revolved around tradition and respect for the mother tongue, Polish literature, history, customs, and, especially, norms of behavior expected by Polish society. The family fulfilled many tasks, not only in relation to its members, but also to the society, by passing on cultural values from generation to generation and creating new systems of values, especially pertinent to given political, social, and cultural conditions that, in addition to guaranteeing safe survival, secured development and progress [7].

Polish culture was saved from being eradicated thanks to the nation's attachment to the land and religion, as well as its will to survive. The role of the family in this process was, without question, unparalleled. Language and faith learned at home provided a feeling of detachment from an alien power; when they were threatened, they became a value to be protected. National awareness grew in importance and a new type of Pole emerged: Catholic, always faithful, and always ready to take up arms.

When insurrections failed, a passive resistance took their place, and the homeland was heroically defended. The Polish home helped develop a feeling of national pride, and well as an internal faith and independence. Poland, a value common to all generations, would strictly integrate families. Polish women played a major role in these troubled times. They were faithful, obedient, but also brave and wise. Thanks to their innate intelligence, they became advisors to their husbands. Emotional and spirited by nature, Polish women taught the young generation to love Poland. They were the guardians of customs, tradition, and religion.

\section{Family as a safeguard of values}

The aim of this article is to present the portrayal of family as an educational environment based on selected literary works from the 19th and 20 th centuries. The studied material was selected according to a specific criterion, i.e., the theme of family as a safekeeper of universal and societal values. With the above in mind, the following works were chosen and analyzed: Kamizelka (The Waistcoat) by Bolesław Prus, Ludzie bezdomni (Homeless People) by Stefan Żeromski, Noce $i$ dnie (Nights and Days) by Maria Dąbrowska, Pan Tadeusz (Sir Thaddeus) by Adam Mickiewicz, and Dolina Issy (The Issa Valley) and Rodzinna Europa (Native Realm) by Czesław Miłosz.

In Kamizelka, Bolesław Prus presents the reader with the greatest of values: family bonds and deep love between spouses. The narrator tells the story about an average married couple who had an ordinary, peaceful life. They were poor, and though they could not afford much, they loved each other deeply and were happy. Their peace is abruptly broken when the husband falls ill, starts feeling worse and worse each day, to the point where he is forced to stop working. The woman tries to comfort her husband, to cheer him up and convince him that he will soon recover. However, the condition worsens. The man starts to lose weight rapidly; he becomes aware of it when putting on his waistcoat, which becomes looser and looser almost each day. Seeing this, his wife secretly shortened the strap in the waistcoat to comfort her loved one. But the man, knowing that his wife is suffering, decides to reassure her, and each day moved the buckle a bit. Finally, one day he sees that he does not have to do it.

In Kamizelka, Prus describes love in a way never seen before. His short story presents spousal love the strength of which does not manifest itself through lofty declarations or a readiness to die for the other person. According to Prus, love rests upon deep respect of a married couple for each other, their attachment, mutual help and care, and support given in difficult times. Characters in the story do not speak about their feelings; instead, the proof of their mutual love lies in their actions. An ordinary waistcoat thus becomes a symbol of a deep feeling connecting the couple, who in face of tragedy resorted to small trickery to spare their loved one the pain and give them hope.

The title of the next work, Ludzie Bezdomni, provides a mental image of people who have no shelter, no place to call their own. However, Zeromski aims to emphasize the metaphorical and symbolic meaning of homelessness, which can be interpreted as the feeling of solitude, alienation, or elimination from society. Homeless people are those who have been forced, whether from political or economic reasons, to abandon their home, their own country. People who due to various causes have no family experience yet another type of homelessness; in a way, they are forced into solitude. After all, home is a symbol of stability in life, family love, warmth, and finally, a place that provides a feeling of security. In the novel, such people include those who shun personal happiness and wealthy life because they wish to change the world (Judym), but also those who for whatever reason were not meant to enjoy the charms of family life (Joasia).

On the other hand, Maria Dąbrowska in her novel Noce $\boldsymbol{i}$ dnie presents family home as a symbol 
of "the first teacher" of each human, a teacher who shapes us and influences our future life in a way we shall never forget. The author describes the history of several generations of a noble family, the Niechcice (Bogumił Niechic and Barbara of Ostrzeńscy Niechcicowa) against the background of momentous societal and political transformations viewed from a double perspective, historical and existential.

The Niechcice struggle with problems characteristic for the time. Bogumił takes care of the land he owns, working hard to provide for his family. Barbara disdains his effort to some extent. She is chimerical and irritable, spending her days reminiscing about her first, unhappy love. She underestimates her husband and yearns after a different, more "inspired" life; rural life bores her. Her children are the recipients of her emotions, especially her boy Tomaszek, insubordinate and difficult to raise. She explains away and hides all of her son's weaknesses, turning him into a cruel egoist. Barbara also sends her elder daughter, Agnieszka, to a good boarding school for girls in Kaliniec. The young girl, eager to learn and curious about the world, quickly becomes independent and begins to follow her own path. During her university studies abroad she engages in political activity.

The life of the Niechcice is difficult and filled with work, but all in all, peaceful and happy. Barbara becomes aware of this only in her later years, after the death of her husband. Despite her difficult personality, she managed to create a true home and teach her children the most important values. Agnieszka, even though she emancipated herself and became independent of her family's influence, entered adulthood with love for her homeland and respect towards the ethical values imbued by her mother.

Adam Mickiewicz's Pan Tadeusz is a literary example of family described as a safekeeper of patriotic values. In the work, the Soplice household constitutes the embodiment of an ideal family home. The head of the house, Judge Soplica, is the keeper of family tradition and values. He pays great attention to etiquette, "an important science of manners"; following it complements respect for tradition and a general philosophy of life based on knowledge about customs, noble genealogy, and social order. The structure of the social order is strictly connected to the functioning of the home and the family.

The young generation is raised to deeply respect the older ones and to heed their opinions. Obedience towards the seniors of the house is the foundation not just of the family, but of the whole country as well: "those who cannot obey their parents will not respect their homeland," the poet seems to say.

Soplicowo is also a Polish court, "a nest of Polishness," a place in which national traditions are cultivated and patriotic ideals are handed down from generation to generation. Seniors teach history in the form of stories and memories. It is upon the family that the patriotic duty rests: subjects prohibited at school are taught by the Polish home. Moreover, home is where valuable mementos are kept, such as a clock that plays Dąbrowski's Mazurka or portraits of national heroes. What the occupier prohibits from being officially cherished is cherished at home, among one's kin. The home in Soplicowo is a veritable fortress, its residents isolated from the occupant in an enclosed space. Furthermore, surrounded by "silent pear trees," the home becomes the abode of the community, open to all fellow Poles, but barred to "strangers" (the occupiers).

Czesław Miłosz in Dolina Issy also proposed that family is the safekeeper of values and a teacher of history. The novel takes place in the Republic of Lithuania in the 1920s. The court in Ginie has belonged to the Surkont family for centuries. The Surkont are relatives of the main character, teenaged Tomasz Dilbin.

Czesław Miłosz describes a world on the verge of revolution: the system of rural life is slowly changing (with the creation of "dairy communes") and disagreements between Poland and Lithuania start to occur (someone throws a grenade into Tomasz's room). It is the family that protects the permanence and inviolability of this place. Tomasz is aware of the origins and difficult history of his family. A connection with his ancestors and a feeling of historical continuity make it easier for the boy to define his identity and attitude towards the world. Without his family in Ginie, he would have been disinherited, lonely, and would have felt crippled. Thus, family performs the most important function in our life, not least because it is in the life and actions of our ancestors that we can recognize ourselves.

The court in Ginie is a picture of Arcadia as seen through the eyes of a child: surrounded by a forest that, resplendent with lush foliage and plentiful wildlife, is separated from the rest of the world and immune to the destructive influence of history. Cultivating ancestral customs and traditions enhances its isolation. The valley of Issa is unique and idyllic; its residents follow patriarchal rules and respect tradition and the rhythm of nature, similar to Soplicowo described above.

Furthermore, in his literary autobiography Rodzinna Europa Miłosz - considering himself 
simultaneously a Pole and a Lithuanian - emphasized the values of family as one's roots. He argues that family is a common heritage, both spiritual and material. Presenting, taking over, or reinterpreting this heritage plays a great role in the creation of personal cultural systems. Inheriting such a common spiritual home allows us to find ourselves and communicate with others. By communing with our home, we help our systems of values develop, which is, as ethicists say, a human soul's most important need, a prerequisite for a human being before he or she can take root in life. Consequently, being uprooted means severing one's ties with tradition and a valuekeeping community; doing so, one loses the chance for finding himself or herself in the world of order and the potential for a harmonious coexistence with people. Creating and maintaining the connection with one's "little homeland" is important in young people's lives: it is, so to say, like tying strings together in the great labyrinth of the world. This is why, as Miłosz writes, awareness of one's origins “is like an anchor line plunged into the deep, keeping one within a certain range" [8].

\section{Summary}

"Literature is a useful and rich source for pedagogy, especially for the theory of family education. The research material collected using literature that concerns the family and the child can perform many a function: inspirational, scholarly, didactic, benchmark, and practical" [4].

When summarizing our musings on family as an education environment, it is vital to emphasize that the theme of family in literature is universal and timeless. This paper presented the various ways in which family is portrayed in the analyzed works, paying special attention to the characteristics of the relationship between its members, as well as indicating the influence of the family home on shaping their personality and future during their later life as adults. Mothers and fathers, as well as the seniors of the house, become spiritual companions in the lives of each character, giving advice, educating, and praising or admonishing. Family provides young persons' lives with values that allow them to live and function in a given social reality. The role of good relationships between family members (between parents and children) in one's life cannot be underestimated, as these relationships guarantees family and personal happiness.

As K. Kabziński writes, "Family, especially the family home, constitutes such an educational environment for a human that not only determines the shaping and development of the young generation, but is also a medium, i.e., the part that connects the past with the present. A broadly-defined home is usually a place that houses tradition and mementos, not only those belonging to the family, but often national ones. It is a place where the faith of one's forefathers is held in respect, the faith in which we observe (...) patterns that should determine the path for the young generation to take" [6].

Such a family home becomes a whole world to a child, especially in his or her earliest years.

M. Lukšienè also indicates the fundamental importance of family home in everyone's education. She proposes that "In natural conditions of life, once a human being reaches adulthood, he or she remains at home" as the caretaker, defender, and user of culture: "he or she enriches, beautifies, and improves the home, because it is there that one finds the purpose and sense of one's life, a guarantee of perfecting one's activity and of continuity of time" [4].

\section{References:}

1. Barkauskaite M., Tijūnelienè O., Meilè Lukšienè - inicjatorka pookupacyjnej reformy oświatowej na Litwie i twórca jej koncepcji. In: Obrazy rodziny w ujeciu pedagogicznym i historycznym. Eds. A. Szerlac, S. Walasek. Wrocław, 2012, p. 219.

2. Boy-Żeleński T., Pieśń o domu malarskim [accessed: May 24, 2013]. <http://pl.wikisource. org/wiki/S\%C5\%82\%C3\%B3wka._Zbi \%-

C3\%B3r_wierszy_i_piosenek/Pie $\%$ C5\%9B\%C5\%84_o_domu_malarskim>.

3. Wychowanie w rodzinie polskiej. Od schytku XVIII do polowy XX wieku. Ed. K. Jakubiak, A. Winiarz. Bydgoszcz, 2000, p. 8.

4. Jałmużno T. Literatura piękna o rodzinie i dziecku (wybrane problemy pedagogiki). In: Rodzina jako środowisko wychowawcze w crasach nowożytnyc. Ed. K. Jakubiak. Bydgoszcz, 1995, p. 167.

5. Jedynak B. Obyczaje domu polskiego w czasach niewoli 1795-1918. Lublin, 1996, p. 6.

6. Kabziński K. Rodzina wiejska jako środowisko wychowawcze w II Rzeczypospolitej. In: Wychowanie w rodzinie polskiej. Od schytku XVIII do połowy XX wieku. Ed. K. Jakubiak, A. Winiarz. Bydgoszcz, 2000, p. 184.

7. Kabzińska L. Rodzina jako podstawowe środowisko wychowawcze w pedagogicznych koncepcjach Królestwa Polskiego. Lata 1864-1918. In: Wychowanie w rodzinie polskiej. Od schyłku XVIII do połowy 
XX wieku. Ed. K. Jakubiak, A. Winiarz. Bydgoszcz, 2000, p. 139.

8. Czesław M. Rodzinna Europa. Warszawa, 1990, p. 102.

9. Nowak-Kowalska M. Potrzeby psychiczne dziecka i postawy rodzicielskie a choroba sieroca [accessed: May 24, 2013]. <http://www. edukacja.edux.pl/p-3317-potrzeby-psychiczne-dziecka-i-postawy-rodzicielskie.php>.

\section{Summary}

Kamila Gandecka

\section{FAMILY. OH! THE FAMILY!” - PORTRAYALS OF FAMILY AS AN EDUCATIONAL ENVIRONMENT IN SELECTED LITERARY WORKS FROM THE 19TH AND 20TH CENTURY}

Portrayals of family as an educational environment are presented based on selected literary works from the 19th and 20th centuries. Pedagogical investigation into this theme intensified in the area of Poland during the Partitions. This was due to the unique role ascribed to the family home, including parents, grandparents, and other members of the family. During that period, family was treated as a safekeeper of universal values and a teacher of history. A family household was rooted in tradition and respect towards the Polish language, literature, history, customs, and norms of behavior. It became synonymous to "the first teacher" in the life of every human. Moreover, family is also a symbol of stability in life, family love, warmth, and a place that provides one with a feeling of security. Thus, the characteristics of family presented in this paper prove that one's ties to the "little homeland" shape him or her in adulthood and determine his or her roots. In her pedagogical concept, M. Lukšienè also indicates the fundamental importance of the family home in the education of the young generation.

University of Wroclaw Institute of Pedagogy 